\title{
Temporal Differences of Urban-Rural Human Biometeorological Factors for Planning and Tourism in Szeged, Hungary
}

\author{
Ronja Vitt, ${ }^{1}$ Ágnes Gulyás, ${ }^{2}$ and Andreas Matzarakis ${ }^{1}$ \\ ${ }^{1}$ Albert-Ludwigs-University Freiburg, 79085 Freiburg, Germany \\ ${ }^{2}$ Department of Climatology and Landscape Ecology, University of Szeged, P.O. Box 653, Szeged 6701, Hungary \\ Correspondence should be addressed to Ronja Vitt; ronja_vitt@gmx.de
}

Received 16 December 2014; Revised 12 March 2015; Accepted 17 March 2015

Academic Editor: Panagiotis Nastos

Copyright (c) 2015 Ronja Vitt et al. This is an open access article distributed under the Creative Commons Attribution License, which permits unrestricted use, distribution, and reproduction in any medium, provided the original work is properly cited.

\begin{abstract}
Heat load and cold stress can provoke annoyance and even health issues. These climatic situations should be avoided by tourists and locals to prevent negative experiences. Thermal comfort indices are required, as they combine meteorological and thermophysiological parameters. The Physiologically Equivalent Temperature (PET) is easy to understand and interpret also for nonexperts like tourists or decision-makers. The Hungarian Meteorological Service and the University of Szeged run an urban and a rural weather station close to Szeged, which build the basis for the human biometeorological analysis for a twelve-year period between 2000 and 2011. The maximum, mean, and minimum air temperature of both stations were compared to detect the differences of thermal dynamics. Heat and cold stress are quantified by analyzing the PET frequencies at 14 CET. The air temperature of urban areas is on average $1.0^{\circ} \mathrm{C}$ warmer than rural areas $\left(11.4^{\circ} \mathrm{C}\right)$. Heat stress is more frequent in urbanized areas $(6.3 \%)$ during summer months at $14 \mathrm{CET}$, while thermal acceptance is more frequent for surrounding rural areas (5.9\%) in the same period. The Climate-Tourism/Transfer-Information-Scheme is a possibility to present the meteorological and human biometeorological data which is interesting for decision-making and tourism in a well-arranged way.
\end{abstract}

\section{Introduction}

Tourism is an important economic sector in Hungary representing $11 \%$ of the Hungarian GDP [1]. In 2011 about $9.8 \%$ of the total employments were directly or indirectly related to the tourism sector. The tourism potential of a region arises from several influencing criteria, such as landscape, flora, fauna, geographical position, topography, culture, leisure opportunities, weather, and climate $[2,3]$. One of the crucial factors for tourists choosing a certain holiday destination is the climatic conditions, followed by scenery and nature [4].

The climatic conditions vary between urbanized and rural districts and therefore have to be investigated separately. The urban climate is altered through the construction of artificial structures and surfaces [5]. Every city has individual thermal dynamics, which form a very heterogeneous microclimate, depending on surface structure, height of the buildings, street width, and numerous other factors. One of the most important effects is the increased heat storage of buildings, which can cause heat stress for human beings during summer as well as a negative impact on recreation and well-being. The heat wave in Europe 2003 recorded predominant human deaths of about 14802 in France, 2045 in the United Kingdom, and 2099 in Portugal [6]. The knowledge of climate information is required for a better tourism planning and for tourism industries. It should help travellers to prepare and adapt to the climatic situation, and it will protect tourists from negative climatic effects like heat stress $[7,8]$. Therefore it is crucial to ascertain the temporal distribution of heat stress situations. Both city-planning and tourism derive advantage from investigations of the urban and rural climatic conditions [9]. It must be pointed out that it is insufficient to evaluate the climatic variables separately. The thermal sensation of humans is a combination of air temperature, wind velocity, water vapour, and radiation fluxes [1012]. There are applicable human-biometeorological indices which combine not only these meteorological parameters but also several personal parameters [13-15]. In this study, 
the biometeorological conditions of a mid-sized city in the south of Hungary and its rural surroundings are analyzed in terms of urban planning and vacation issues. The mean, minimum, and maximum air temperature for urban and rural areas around Szeged are presented. In order to quantify thermal stress conditions, the frequencies of PET classes, as well as the precipitation conditions, for each ten-day interval of the year were analyzed. The Climate-Tourism/Transfer-Information-Scheme gives a clearly arranged overview of the most important meteorological and human-biometeorological factors which influence tourism potential and recreation. This paper offers a bioclimatic information scheme developed for tourism purposes for the medium-sized Hungarian city of Szeged that could be used also for urban planning. It compares thermal and climatic differences between the city and its surroundings. Meteorological data comes from one urban and one rural station and covers the period from 2000 to 2011.

\section{Materials and Methods}

In this study, meteorological and human-biometeorological conditions of Szeged were analyzed. The city is located in the south of Hungary in a huge plain, the so-called Carpathian/Pannonian basin (Figure 1). Szeged is a midsized city with 170000 inhabitants and has a circuit street system. The data for the period 2000-2011 is provided by the Hungarian Meteorological Service and the University of Szeged and has a time resolution of one hour [16, 17]. The rural synoptic weather station is surrounded by grassland and is located in the west of the city center of Szeged (Figure 1(c)). The climate station in the heavily built-up city center is separated; some measurement tools are located on the top of the roof of a university building, while the Stevenson screen is situated on a lawn beneath the roof station, in order to conform to international regulations.

Evaluating the influence of meteorological parameters on human beings, various thermal indices have been established, which can be classified into three categories: elementary, bioclimatic, and combined indices. Elementary indices usually attach single parameters such as air temperature, sunshine duration, and precipitation. The required synthetic values do not have any thermophysiological relevance and are mostly unproven [7]. Bioclimatic and combined indices, such as the Tourism Climate Index (TCI) or the Physiologically Equivalent Temperature (PET), take account of several climatological parameters and also combine their effects. The TCI developed by Mieczkowski [19] includes seven climatological factors: two of them are in a bioclimatic combination (Daytime comfort index and Daily comfort index) and three are independent (precipitation, sunshine, and wind velocity). The weak point of this index is that it does not rely on the human energy balance. Recognising this weakness, Kovács and Unger $[20,21]$ have aimed and presented methods to replace the air temperature and relative humidity values as the basis of Daytime and Daily comfort indices of the TCI with the human-biometeorological index PET. In addition to TCI, there are indices which include the effects of short- and longwave radiation fluxes on the human body, such as Predicted
TABLE 1: Threshold values of Physiologically Equivalent Temperature (PET) for thermal sensation and the physiological stress level of human beings [18].

\begin{tabular}{lcc}
\hline PET $\left({ }^{\circ} \mathrm{C}\right)$ & Thermal sensation & Physiological stress level \\
\hline 4 & Very cold & Extreme cold stress \\
8 & Cold & Strong cold stress \\
13 & Cool & Moderate cold stress \\
18 & Slightly cool & Slight cold stress \\
23 & Comfortable & No thermal stress \\
29 & Slightly warm & Slight heat stress \\
35 & Warm & Moderate heat stress \\
41 & Hot & Strong heat stress \\
\hline
\end{tabular}

Mean Vote (PMV) [22], Standard Effective Temperature $\left(\mathrm{SET}^{*}\right.$ ) [23], Universal Thermal Climate Index (UTCI) [24], or Physiologically Equivalent Temperature (PET) [25-27]. The parameter used in this study is PET, which is defined as the assessed air temperature under complex outdoor conditions, at which the human energy budget is balanced at typical indoor conditions. In order to calculate PET, several parameters such as air temperature, wind velocity, relative humidity, or vapour pressure and global radiation are needed. PET is an indicator for thermophysiological stress and its values are given in ${ }^{\circ} \mathrm{C}$, which makes it easy to interpret and understand also for nonexperts (Table 1) [26]. The calculations for PET have been done by the use of RayMan model $[28,29]$. For analyzing the annual distribution, a PET frequency diagram at 14 CET (Central European Time) for the urban station was made for 10-day periods, as this time span comes very close to the mean vacation duration $[30,31]$. In addition, the average maximum, mean, and minimum air temperature in urbanized and rural areas were analyzed.

More detailed information about tourism relevant to climatological and bioclimatological parameters can be illustrated in the Climate-Tourism/Transfer-Information-Scheme (CTIS). The threshold for the included thermal, aesthetic, and physical facets is chosen as follows $[30,32,33]$ :

\section{Thermal Facet}

(i) thermal acceptance $\left(18.0^{\circ} \mathrm{C}<\mathrm{PET}<29.0^{\circ} \mathrm{C}\right)$,

(ii) heat stress $\left(\mathrm{PET}>35.0^{\circ} \mathrm{C}\right.$ ),

(iii) cold stress $\left(\mathrm{PET}<4.0^{\circ} \mathrm{C}\right)$.

\section{Aesthetic Facet}

(i) cloudiness (cloud cover $<4$ ),

(ii) fog (relative humidity $>93 \%$ ). 


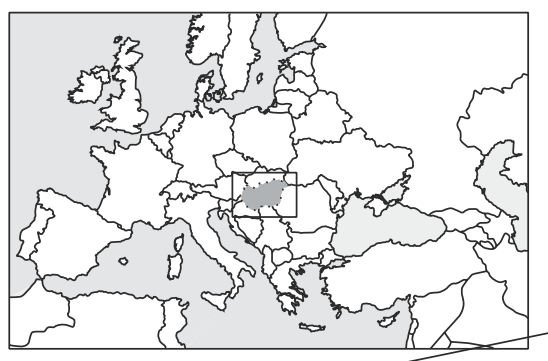

(a)

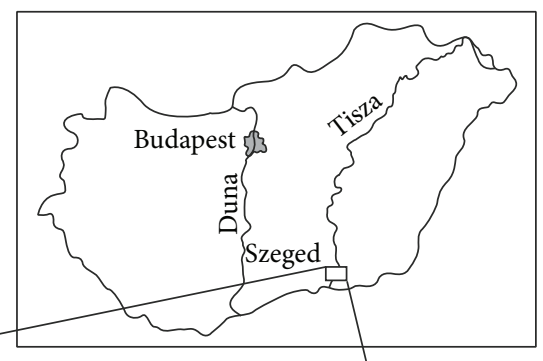

(b)

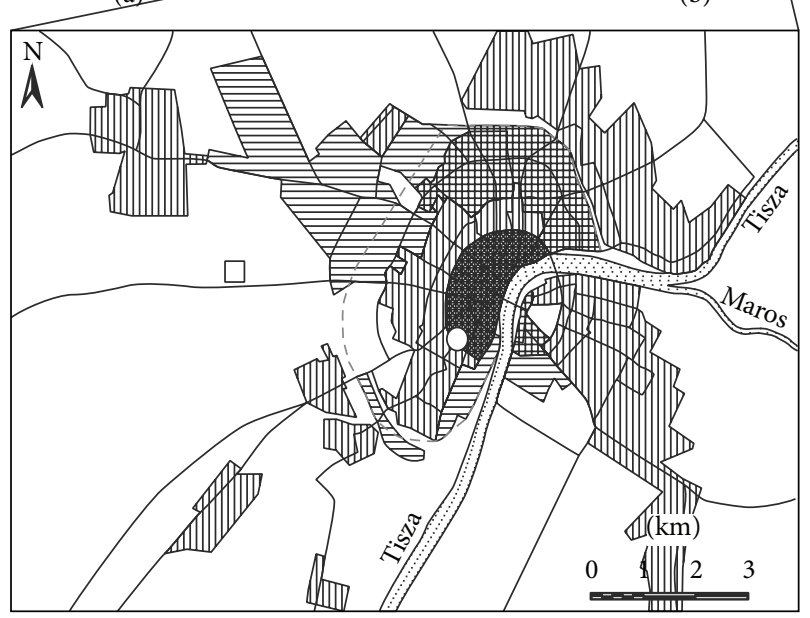

(c)

FIGURE 1: Geographical location of Hungary in Europe (a) and of Szeged in Hungary (b) and characteristic land-use types and road network of Szeged (c); A: road; B: circle dike; C: measuring point in the city centre (O) and in the rural area ( $\square$ ); D: agricultural area; E: industrial area; F: 1-2-storey detached houses; G: 5-11-storey apartment buildings; H: historical city core with 3-5-storey buildings (modified after [36]).

\section{Physical Facet}

(i) sultriness (vapour pressure $>18 \mathrm{hPa}$ ),

(ii) windy (wind velocity $>8 \mathrm{~m} / \mathrm{s}$ ),

(iii) dry days (precipitation $<1 \mathrm{~mm}$ ),

(iv) wet days (precipitation $>5 \mathrm{~mm}$ ).

In CTIS, the absolute frequencies and probabilities of these factors are given in 10-day intervals. To make the information easier to understand for tourists and the tourism industry, each factor given in CTIS can be ranked as positive or negative and will be categorized in seven classes from "very poor" to "ideal." As heat stress, cold stress, fog, sultriness, windy, and wet days are not favourable for tourism, these factors are ranked as negative. On the other hand, thermal acceptance, cloudiness, and dry days are presumed to be beneficial for tourism. This means that a high probability of heat stress is categorized as "very poor," whereas a high probability of thermal acceptance is evaluated as "ideal."

\section{Results}

3.1. Annual Course of the Maximum, Mean, and Minimum Air Temperature. The annual courses of the maximum, mean, and minimum air temperature in rural and urbanized areas are shown in Figure 2 for each ten-day interval of the year. Rural areas show marginal lower air temperature than urban areas from November until May and become higher from June to October. In the city of Szeged, $T_{a, \max }$ is up to $0.8^{\circ} \mathrm{C}$ higher in April and up to $0.5^{\circ} \mathrm{C}$ lower in September and October compared to its surroundings. In general, $T_{a, \max }$ of urban areas ranges from $2.5^{\circ} \mathrm{C}$ to $29.1^{\circ} \mathrm{C}$ and in rural areas ranges from $2.1^{\circ} \mathrm{C}$ to $29.3^{\circ} \mathrm{C}$. The lowest $T_{a, \max }$ occurs in December and January, and the highest $T_{a, \max }$ occurs in July. The annual mean air temperature of urban areas is $12.4^{\circ} \mathrm{C}$, while rural areas in the region of Szeged are $1.0^{\circ} \mathrm{C}$ cooler. The coldest period of the urban and rural areas is the first ten-day interval of January with $0.1^{\circ} \mathrm{C}$ and $-0.8^{\circ} \mathrm{C}$, and the warmest period occurs in the second ten-day interval of July with $23.9^{\circ} \mathrm{C}$ and $22.9^{\circ} \mathrm{C}$, respectively. In the winter months (December to February), the urban areas have an average 


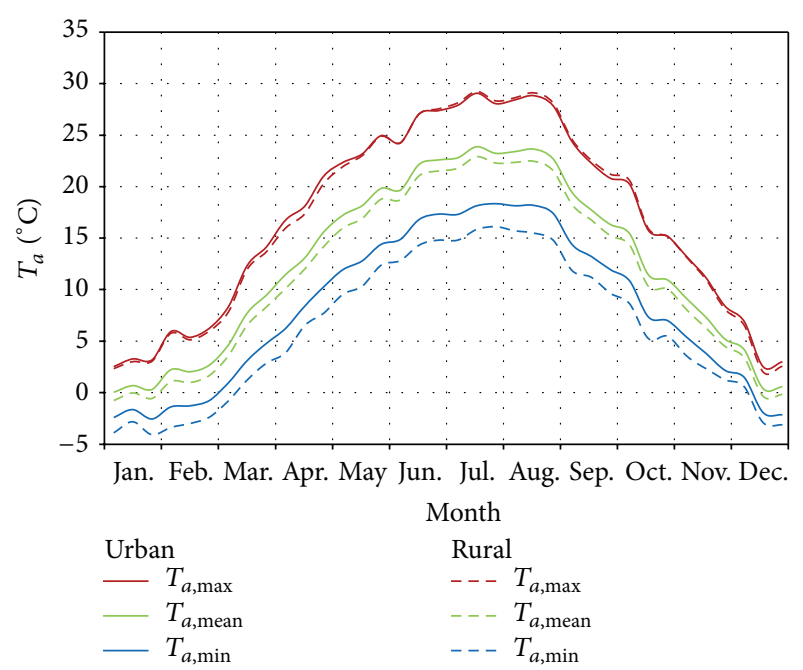

FIgURE 2: Mean annual course of the maximum, mean, and minimum air temperature for urban and rural areas of Szeged.

$T_{a \text {,mean }}$ of $1.5^{\circ} \mathrm{C}$, which is about $0.9^{\circ} \mathrm{C}$ warmer than in rural areas. In summer (June to August), it is even $1.1^{\circ} \mathrm{C}$ warmer, with an average $T_{a \text {,mean }}$ of $22.7^{\circ} \mathrm{C}$. The highest differences of $T_{a \text {,mean }}$ between urban and rural areas occur during summer and add up to $1.4^{\circ} \mathrm{C}$. The average minimum air temperature of rural areas compared to the city of Szeged is $1.5^{\circ} \mathrm{C}$ lower in winter and $2.6^{\circ} \mathrm{C}$ lower in summer. It varies from $-2.5^{\circ} \mathrm{C}$ to $18.5^{\circ} \mathrm{C}$ in urban areas and for rural areas $T_{a \text {,min }}$ varies from $-4.1^{\circ} \mathrm{C}$ to $16.0^{\circ} \mathrm{C}$. The lowest values of $T_{a, \min }$ occur in January and the highest values occur in July for both areas.

\subsection{Physiologically Equivalent Temperature for Urban Areas} at 14 CET. The values of PET in the urbanized areas at $14 \mathrm{CET}$ are grouped into the classes of thermal sensation and physiological stress level (Figure 3). The class frequencies are shown for each ten-day interval of the year. Due to this well-arranged diagram, it is easy to detect the occurrence and probability of thermal comfort, heat, and cold stress. In the urbanized area the mean annual PET is $19.3^{\circ} \mathrm{C}$, with maximum values up to $48.9^{\circ} \mathrm{C}$ and minimum values up to $-15.8^{\circ} \mathrm{C}$. The range of PET values for the rural surroundings ranges from $-20.5^{\circ} \mathrm{C}$ up to $50.6^{\circ} \mathrm{C}$, with an average of $17.8^{\circ} \mathrm{C}$. Expressed in the thermal sensation scale, the meteorological conditions in Szeged and its outer conurbation area go from "very cold" to "very hot," which are the upper extremes of the scale.

Between the first ten-day interval of November and the first ten-day interval of May, cold stress $\left(\mathrm{PET}<4.0^{\circ} \mathrm{C}\right)$ can occur. The probability of cold stress increases rapidly from $8.3 \%$ in the first ten-day interval of November to $35.8 \%$ in the third ten-day interval of November. In December the occurrence triples and up to four of five days show PET values $<4.0^{\circ} \mathrm{C}$. In winter (December until February) cold stress dominates at almost two-thirds of the days. In December and January the PET values do not exceed $18.0^{\circ} \mathrm{C}$, whereas in February the first comfortable days $\left(18.0^{\circ} \mathrm{C}<\mathrm{PET}<29.0^{\circ} \mathrm{C}\right)$ can occur. During winter months the urbanized areas of

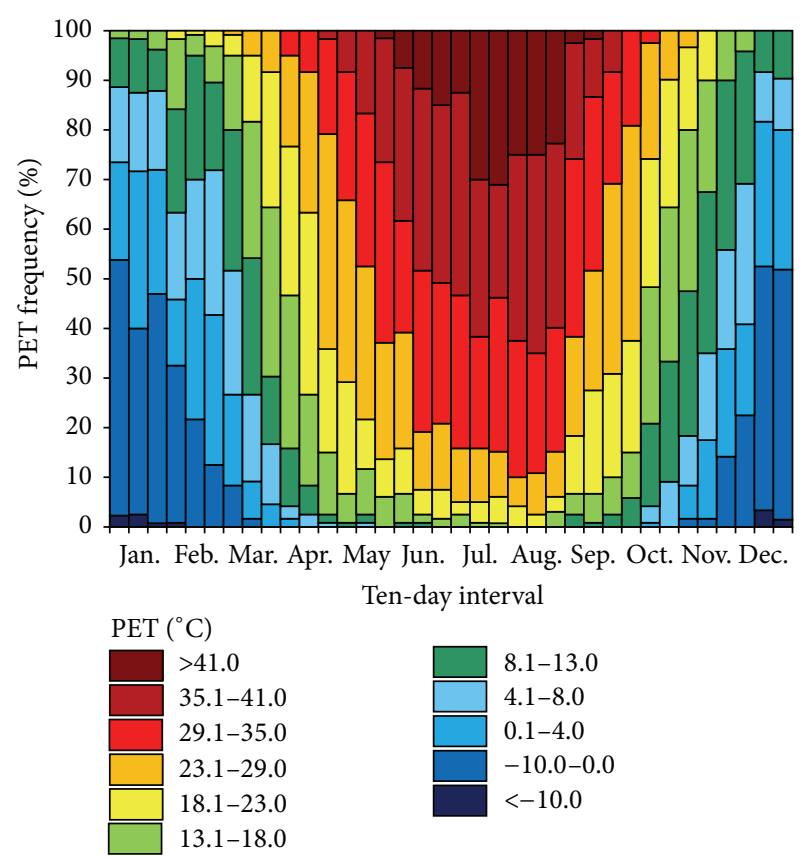

FIgure 3: Frequency diagram of PET at 14 CET based on ten-day intervals for urban areas.

Szeged have an average PET value of $2.4^{\circ} \mathrm{C}$ at $14 \mathrm{CET}$. While in February thermal acceptance has a probability of 1.9\%, which is about one day every second year: it increases during spring (March until May) with at least $40 \%$ of the days. The second ten-day interval of April shows the highest probability of thermal acceptance $(65.0 \%)$ and neither cold nor heat stress occurs. At an average of 18 days in April thermal acceptance is expected and the probability of heat and cold stress is less than $1 \%$. In March, there is still a slight chance of cold stress, while in May almost every fifth day produces heat stress. In spring the mean PET at $14 \mathrm{CET}$ is thermally comfortable in general, with an average of $20.5^{\circ} \mathrm{C}$.

Heat stress $\left(\mathrm{PET}>35.0^{\circ} \mathrm{C}\right)$ may occur between the third ten-day interval of April and the third ten-day interval of August. During summer months (June until August) heat stress occurs on average every second day (54.8\%), while there is a minor chance of thermal acceptance (16.0\%). The average value of PET at $14 \mathrm{CET}$ during summer is $34.9^{\circ} \mathrm{C}$. The highest risk of heat stress is given in August with an average of $62.4 \%$ and accordingly about 19 days, while there are only 3 days which are thermally comfortable. In autumn (September until November) the number of comfortable days increases rapidly. Thermal acceptance already dominates in September with $45.3 \%$ compared to $15.8 \%$ of heat stress. Neither heat stress nor cold stress occurs in October and every second day $(50.3 \%)$ is expected to be thermally comfortable. Per year there are about 67 days of cold stress and 61 days of heat stress in the city of Szeged, while at least 84 days are thermally comfortable. The majority of the comfortable days are detected in spring and autumn. The frequencies of PET classes are very similar for rural areas and therefore not shown in a figure separately. In general, cold stress is more frequent (78 days per year) and heat stress occurs less 


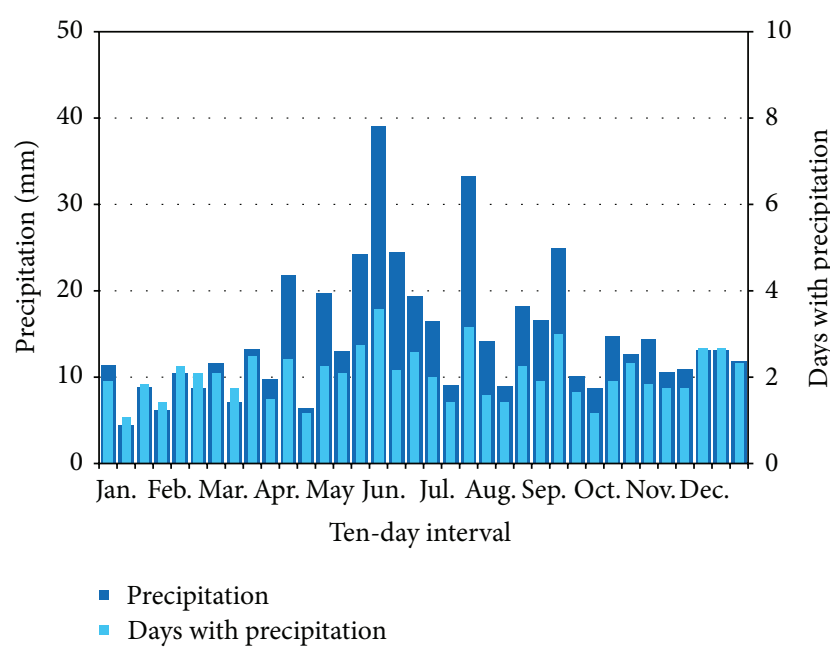

FIGURE 4: Total amount of precipitation and amount of days with precipitation ( $R R>1 \mathrm{~mm}$ ) per ten-day interval at the urban station.

frequently (53 days per year), while there is no difference for thermally comfortable days between urban and rural areas.

3.3. Precipitation in Szeged. In Szeged there are on average 73 days with precipitation per year at a total amount of $520 \mathrm{~mm}$. Most of the precipitation falls during summer, with a maximum of $82 \mathrm{~mm}$ in June falling within 8 days (Figure 4). Compared to $25 \mathrm{~mm}$ within 5 days in January, the winter precipitation events are less intensive than during summer. Between May and July precipitation events occur during $24 \%$ of the days. There are only marginal differences of precipitation between the urban and the rural station, due to the relatively short horizontal distance between the stations and the homogeneous area.

3.4. Climate-Tourism/Transfer-Information-Scheme. In Figure 5, the probability of thermal acceptance, heat and cold stress, cloudiness, fog, sultriness, wind, and dry and wet days at the urban station are shown for 14 CET for each ten-day interval. In April and October, up to $70 \%$ of the days are thermally comfortable, while during summer there are only on average 5 days per month with high thermal comfort. Regarding the difference between the urban and the rural station (Figure 6), it is noticeable that during spring and autumn the probability of thermal acceptance is up to $20 \%$ lower in the city than at the rural station, but there is a higher chance during summer months.

Heat stress is possible from May until September, with the highest probabilities in July and August, when PET exceeds $29.0^{\circ} \mathrm{C}$ for almost two-thirds of the days. In rural areas heat stress occurs less frequently than in urban areas. Between October and April cold stress might occur; in the second tenday interval of December $84 \%$ of the days cause cold stress. In general, two out of three days show a PET below $4.0^{\circ} \mathrm{C}$ during winter months. At the rural station, the possibility of cold stress is slightly higher than at the urban station (Figure 6).
Mean annual cloud cover of Szeged is 5 octas, with small differences between the seasons. During summer it is up to $40 \%$ less cloudy than during winter months. Sultriness can occur in May and October, with the highest probability of $30 \%$ in July and August. Wind and fog seem to have almost no impact on the human well-being in the region of Szeged, as they hardly exceed the given threshold values.

Generally eight out of ten days are presumed to be dry days, with less than $1 \mathrm{~mm}$ of precipitation per day. About 33 days of the year are wet days with more than $5 \mathrm{~mm}$ of precipitation. There are only little annual differences in the amount of dry and wet days.

\section{Discussion}

The differences of the air temperature and PET between the urban and the rural area are a result of the anthropogenic urban structures. The energy balance in urbanized areas is influenced by the composition, degree of sealing, surface roughness, street orientation, and thermal characteristics. Due to the alteration of land surfaces in cities, the materials absorb and accumulate short-wave radiation, which will be emitted as heat radiation. Weak wind conditions in cities facilitate the development of the UHI, which occurs especially in winter and summer during nighttime [34]. Therefore the mean annual air temperature at the urban station is about $1.0^{\circ} \mathrm{C}$ higher than at the rural station. Regarding PET, the rural station shows a mean value of $8.1^{\circ} \mathrm{C}$ and the urban station shows a mean value of $9.8^{\circ} \mathrm{C}$.

The urban and rural human-biometeorological conditions of Szeged were compared by using the Thermohygrometric Index THI, the Relative Strain Index RSI, and the number of beer garden days for a 3-year period [35]. On the scale of THI, $6 \%$ of the year was "hot" in urban areas, while in rural areas it was only $1 \%$. Cold conditions occurred for $54 \%$ and $66 \%$ in urban and rural areas, respectively. Beer garden days occur almost twice as often as in urban areas between May and October. Gulyás et al. [36] and Gulyás and Unger [37] made further studies about the humanbiometeorological situation in Szeged, using hourly PET frequencies over a 10-year period from 1999 until 2008. The mean annual PET value for urban areas is $2.9^{\circ} \mathrm{C}$ higher than for rural areas. While the maximum PET values are insignificantly higher $\left(0.9^{\circ} \mathrm{C}\right)$, the minimum PET values are $10.6^{\circ} \mathrm{C}$ higher in urban areas compared to rural areas. Thermal acceptance occurs almost twice as often in urban areas. Findings were that rural areas have a higher frequency of extreme cold and extreme heat stress. The heat wave of 2003 was investigated separately [17]. The examined period was March until November 2003, concluding that extreme heat stress occurs more frequently in rural areas due to direct radiation, which decreases in urbanized areas. Even though the average annual PET value is $14 \%$ higher in urban areas, thermal acceptance occurs twice as often. The difference in PET is the highest after sunset, when the urban areas are 7$8^{\circ} \mathrm{C}$ warmer due to the decreased cooling effect. These studies coincide with our results.

The human thermal differences in Budapest, Hungary, expressed with the PET were investigated by comparing 


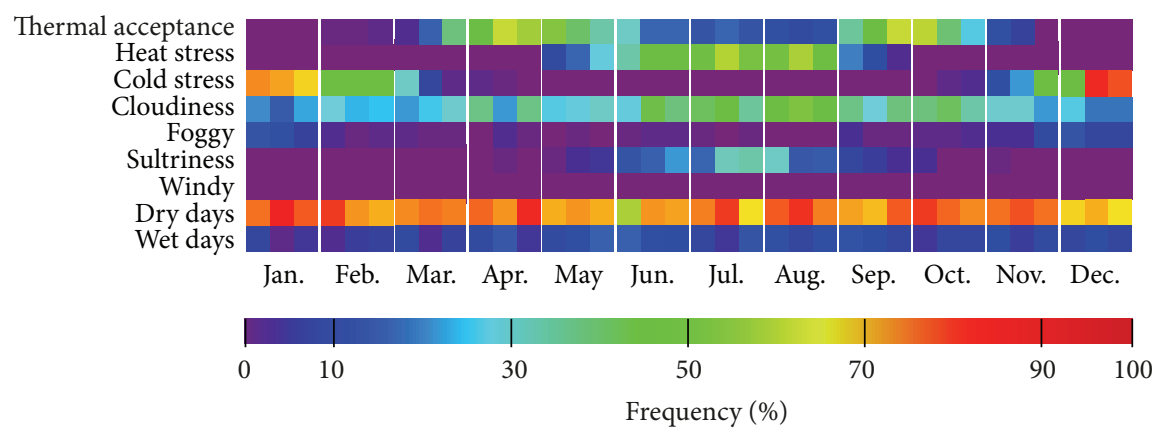

(a)

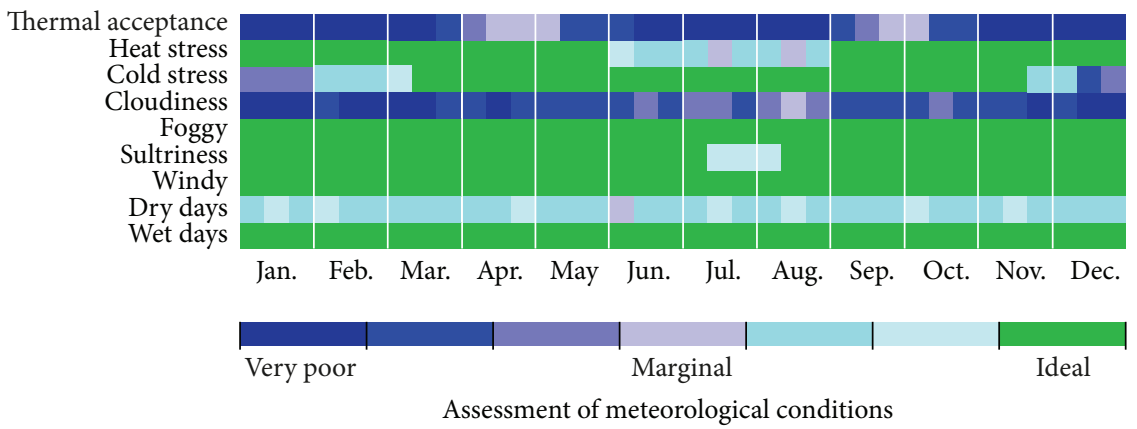

(b)

FIGURE 5: Climate-Tourism/Transfer-Information-Scheme (CTIS) for the urban station at 14 CET shown in relative frequencies (a) and as evaluated parameters (b).

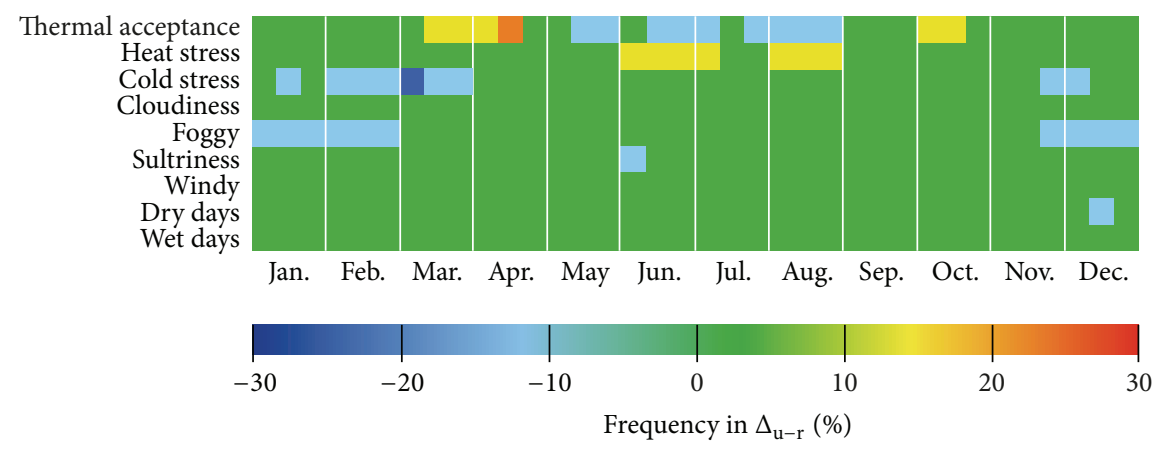

FIGURE 6: Difference of frequency between the urban and the rural station at 14 CET.

measurements of weather stations situated in the central and the suburban area [38]. They found that the PET differences are the same in all characteristic diurnal observation times $(0$, 6, 12, and 18 UTC) in the periods 1961-1990 and 1981-2010: the heat load is stronger and the cold stress level is less in the city centre than in the suburbs. During the period from 2001 until 2010 the average PET value is higher by $3^{\circ} \mathrm{C}$ in the city centre. The maximum PET is only slightly higher $\left(0.9^{\circ} \mathrm{C}\right)$ here, but the difference in the minimum value is much higher, about $5^{\circ} \mathrm{C}$. The tendencies are similar to those in Gulyás et al. [36] and Gulyás and Unger [37].

The biometeorological comfort of rural urban and urban forest in Erzurum, Turkey, were determined by using the THI [39]. Erzurum has a continental climate and a population of about 361235 . Unlike this study, they stated that the urban area is most advantageous for human comfort, followed by the urban forest and rural area. It has to be considered that the THI is based only on air temperature and relative humidity. The cooling effect of wind is not involved, which is usually higher in rural areas than in urban areas, due to urban structures. The differences of urban, suburban, and rural districts over Greater Cairo in Egypt, which has a subtropical climate, were investigated [40]. As well as Balogun et al. [41], Robaa [40] ascertained that the urban areas are in general warmer than its surroundings.

In our study a more complex system was used; hence, it is of higher significance. Not only the difference of air temperature between urban and rural areas but also PET was compared. We analyzed the mean, maximum, and minimum air temperature, the frequency of PET classes 
at $14 \mathrm{CET}$, and arranged the most important meteorological information for planning and tourism in a ClimateTourism-Information-Scheme. Tourists can easily ascertain favourable and unfavourable conditions to plan their vacation for their individual needs. Zaninović and Matzarakis [31] designed a bioclimate leaflet, which includes climatological and bioclimatological information of a city or region for tourists. It is an application to assist the tourism industry and stakeholders in decision-making, as well as tourists themselves. The information which is contained could help tourist planners in order to extend the tourist season, and it could help tourists to find the best individual period for their vacation. The design of the leaflet is easy to understand and gives a broad and compact overview of the climatological conditions of the destination.

\section{Conclusion}

In this study, meteorological and human-biometeorological parameters of urban and rural areas of Szeged were analyzed and the temporal differences of thermal conditions were discovered. There are differences for PET values during the day, as in summer heat stress occurs more frequently in urban areas at $14 \mathrm{CET}$, and thermal acceptance is more probable in the rural surroundings. On the contrary, cold stress is more frequent in rural areas during winter, due to the absence of heat storage of buildings and low wind speed. Based on the little horizontal distance between the urban and the rural station, there are marginal differences of precipitation.

Single weather parameters, usually presented on a monthly basis, are not appropriate for planning in tourism and urban structures. The Climate-Tourism-InformationScheme visualizes the most important weather and climate information which is useful for tourism and recreation. It might be helpful for planning a vacation and to know more about the climatic conditions than the usually given meteorological forecast. Information about biometeorological conditions can detect the risk of heat or cold stress whereby the tourists can adapt. The CTIS is user-friendly and easy to understand also for nonexperts like tourists and it gives an overview about the most important climatic and biometeorological parameters.

\section{Conflict of Interests}

The authors declare that there is no conflict of interests regarding the publication of this paper.

\section{References}

[1] World Travel and Tourism Council, Eds., Travel and Tourism, Economic impact 2012 Hungary, 2012.

[2] D. R. Hall, "The challenge of international tourism in eastern Europe," Tourism Management, vol. 13, no. 1, pp. 41-44, 1992.

[3] D. R. Hall, "Tourism development and sustainability issues in Central and South-eastern Europe," Tourism Management, vol. 19, no. 5, pp. 423-431, 1998.

[4] W. Lise and R. S. J. Tol, "Impact of climate on tourist demand," Climatic Change, vol. 55, no. 4, pp. 429-449, 2002.
[5] A. Matzarakis, Die thermische Komponente des Stadtklimas, vol. 6, Berichte des Meteorologischen Institutes der Universität Freiburg, 2001.

[6] World Health Organization Europe, Heat-Waves: Risks and Responses. Health and Global Environmental Change, Series No. 2, World Health Organization, Regional Office for Europe, Copenhagen, Denmark, 2004.

[7] A. Matzarakis, "Weather- and climate-related information for tourism," Tourism and Hospitality Planning \& Development, vol. 3, no. 2, pp. 99-115, 2006.

[8] A. Matzarakis, "Climate, thermal comfort and tourism," in Climate Change and Tourism: Assessment and Coping Strategies, B. Amelung, K. Blazejczyk, and A. Matzarakis, Eds., pp. 139-154, 2007.

[9] C. R. de Freitas, “Tourism climatology: Evaluating environmental information for decision making and business planning in the recreation and tourism sector," International Journal of Biometeorology, vol. 48, no. 1, pp. 45-54, 2003.

[10] A. Matzarakis, "Entwicklung einer Bewertungsmethodik zur Integration von Wetter und Klimabedingungen im Tourismus," Berichte des Meteorologischen Institutes der Universität Freiburg, vol. 16, pp. 73-80, 2007.

[11] K. Büttner, Physikalische Bioklimatologie, Akademische Verlagsgesellschaft, Leipzig, Germany, 1938.

[12] N. E. Davis, "An optimum weather index," Weather, vol. 23, no. 8, pp. 305-317, 1968.

[13] P. R. Höppe, “Heat balance modelling," Experientia, vol. 49, no. 9, pp. 741-746, 1993.

[14] P. Höppe, "Aspects of human biometeorology in past, present and future," International Journal of Biometeorology, vol. 40, no. 1, pp. 19-23, 1997.

[15] H. Mayer, "Urban bioclimatology," Experientia, vol. 49, no. 11, pp. 957-963, 1993.

[16] Á. Gulyás and A. Matzarakis, "Seasonal and spatial distribution of PET-physiologically equivalent temperature (PET) in Hungary," Idöjárás, vol. 113, no. 3, pp. 221-231, 2009.

[17] Á. Gulyás, A. Matzarakis, and J. Unger, "Differences in the thermal bioclimatic conditions on the urban and rural areas in a southern Hungarian city (Szeged)," in Berichte des Meteorologischen Institutes der Universität Freiburg, H. Mayer and A. Matzarakis, Eds., vol. 18, pp. 229-234, 2009.

[18] A. Matzarakis and H. Mayer, "Another kind of environmental stress: thermal stress," in WHO Collaborating Centre for Air Quality Management and Air Pollution Control, vol. 18, pp. 710, 1996.

[19] Z. Mieczkowski, “The tourism climatic index: a method of evaluating world climates for tourism," The Canadian Geographer, vol. 29, no. 3, pp. 220-233, 1985.

[20] A. Kovács and J. Unger, "Modification of the tourism climatic index to central European climatic conditions-examples," Quarterly Journal of the Hungarian Meteorological Services, vol. 118, no. 2, pp. 147-166, 2014.

[21] A. Kovács and J. Unger, "Analysis of tourism climatic conditions in Hungary considering the subjective thermal sensation characteristics of the South-Hungarian residents," Acta Climatologica et Chorologica, vol. 47-48, pp. 77-84, 2014.

[22] P. O. Fanger, Thermal Comfort, McGraw-Hill, New York, NY, USA, 1972.

[23] A. P. Gagge, A. P. Fobelets, and L. G. Berglund, "A standard predictive index of human response to the thermal environment," ASHRAE Transactions, vol. 92, pp. 709-731, 1986. 
[24] G. Jendritzky, R. de Dear, and G. Havenith, "UTCI-why another thermal index?" International Journal of Biometeorology, vol. 56, no. 3, pp. 421-428, 2012.

[25] P. Höppe, "The physiological equivalent temperature-a universal index for the biometeorological assessment of the thermal environment," International Journal of Biometeorology, vol. 43, no. 2, pp. 71-75, 1999.

[26] A. Matzarakis, H. Mayer, and M. G. Iziomon, "Applications of a universal thermal index: physiological equivalent temperature," International Journal of Biometeorology, vol. 43, no. 2, pp. 76-84, 1999.

[27] H. Mayer and P. Höppe, "Thermal comfort of man in different urban environments," Theoretical and Applied Climatology, vol. 38, no. 1, pp. 43-49, 1987.

[28] A. Matzarakis, F. Rutz, and H. Mayer, "Modelling radiation fluxes in simple and complex environments-application of the RayMan model," International Journal of Biometeorology, vol. 51, no. 4, pp. 323-334, 2007.

[29] A. Matzarakis, F. Rutz, and H. Mayer, "Modelling radiation fluxes in simple and complex environments: basics of the RayMan model," International Journal of Biometeorology, vol. 54, no. 2, pp. 131-139, 2010.

[30] A. Matzarakis, "Transferring climate information for application and planning - the Climate-Tourism/Transfer-Information-Scheme," in Advances in Meteorology, Climatology and Atmospheric Physics, C. G. Helmis and P. Nastos, Eds., vol. 1 of Springer Atmospheric Sciences, pp. 591-597, Springer, Berlin, Germany, 2013.

[31] K. Zaninović and A. Matzarakis, "The bioclimatological leaflet as a means conveying climatological information to tourists and the tourism industry," International Journal of Biometeorology, vol. 53, no. 4, pp. 369-374, 2009.

[32] A. Matzarakis, "Assessment method for climate and tourism based on daily data," in Developments in Tourism Climatology, A. Matzarakis, C. R. de Freitas, and D. Scott, Eds., pp. 52-58, 2007.

[33] A. Matzarakis, "Transfer of climate data for tourism applications-the climate-tourism/transfer-information-scheme," Sustainable Environmental Research, vol. 24, no. 4, pp. 273-280, 2014.

[34] J. Unger, "Modelling of the annual mean maximum urban heat island using 2D and 3D surface parameters," Climate Research, vol. 30, no. 3, pp. 215-226, 2006.

[35] J. Unger, "Comparisons of urban and rural bioclimatological conditions in the case of a Central-European city," International Journal of Biometeorology, vol. 43, no. 3, pp. 139-144, 1999.

[36] Á. Gulyás, A. Matzarakis, and J. Unger, "Comparison of the urban-rural thermal comfort sensation in a city with warm continental climate," in Berichte des Meteorologischen Instituts der Universität Freiburg, A. Matzarakis, H. Mayer, and F.-M. Chmielewski, Eds., vol. 20, pp. 473-478, 2010.

[37] Á. Gulyás and J. Unger, "Analysis of bioclimatic loads inside and outside the city in a long-term and an extremely short-term period (Szeged, Hungary)," Urban Climate News, vol. 37, pp. 1114, 2010.

[38] A. Kovács and Á. Németh, "Tendencies and differences in human thermal comfort in distinct urban areas in Budapest, Hungary," Acta Climatologica et Chorologica, vol. 46, pp. 115124, 2012.

[39] S. Toy, S. Yilmaz, and H. Yilmaz, "Determination of bioclimatic comfort in three different land uses in the city of Erzurum,
Turkey," Building and Environment, vol. 42, no. 3, pp. 1315-1318, 2007.

[40] S. M. Robaa, "Urban-suburban/rural differences over Greater Cairo, Egypt," Atmósfera, vol. 16, no. 3, pp. 157-171, 2003.

[41] A. A. Balogun, I. A. Balogun, and Z. D. Adeyewa, "Comparisons of urban and rural heat stress conditions in a hot-humid tropical city," Global Health Action, vol. 3, pp. 1-5, 2010. 

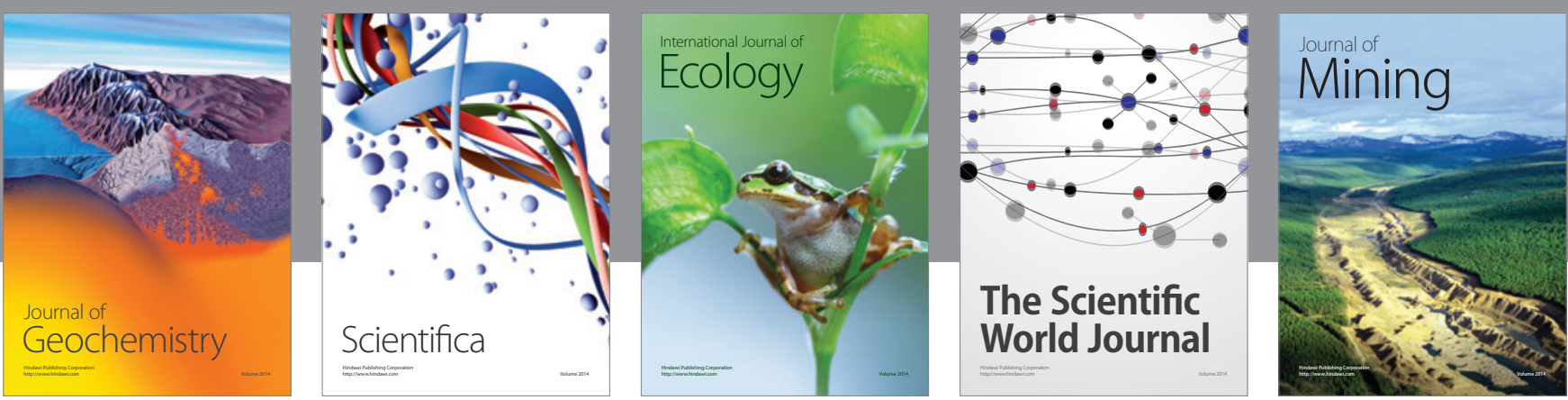

The Scientific World Journal
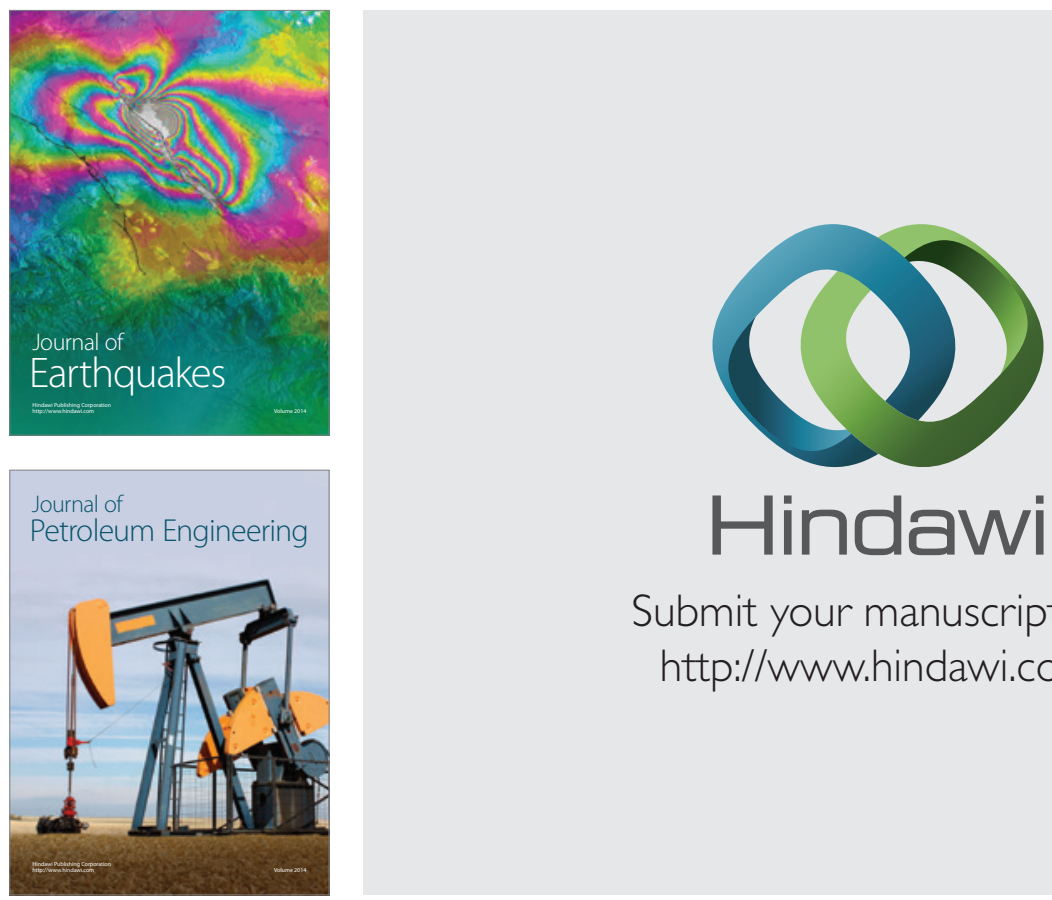

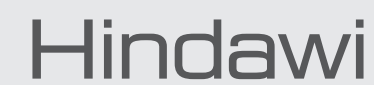

Submit your manuscripts at

http://www.hindawi.com
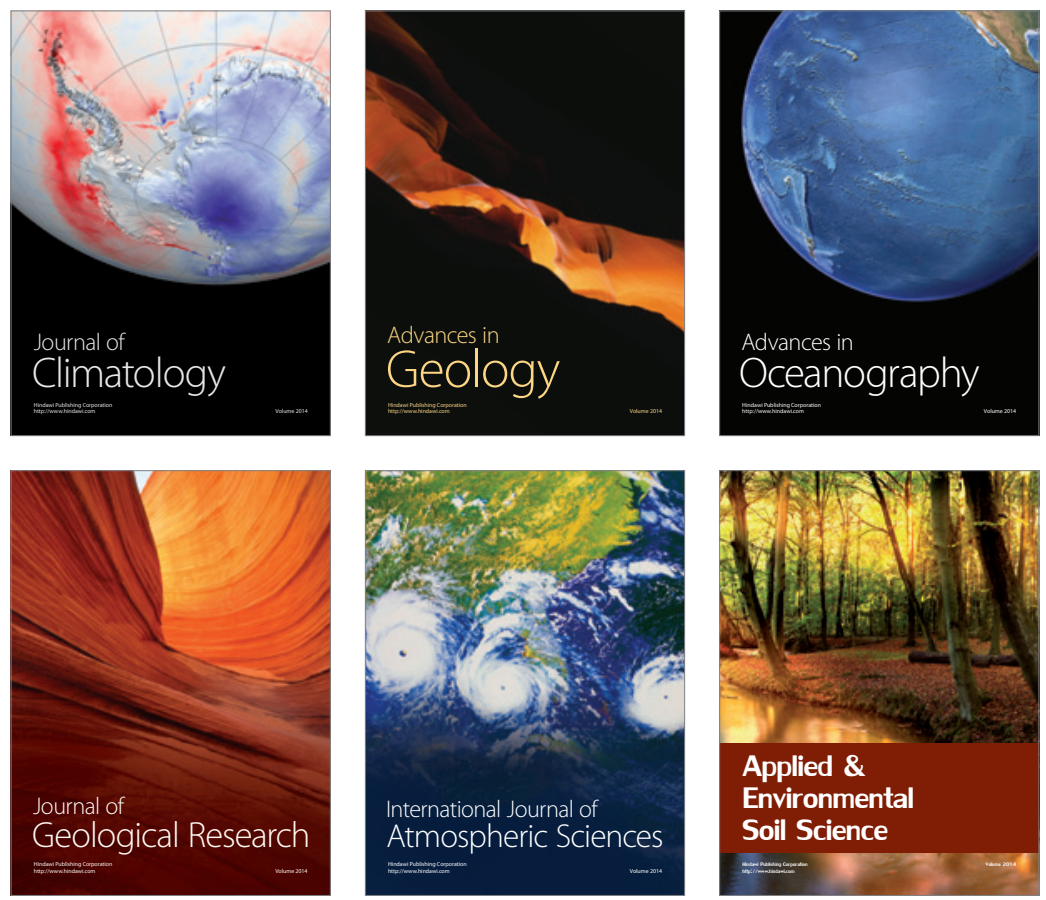
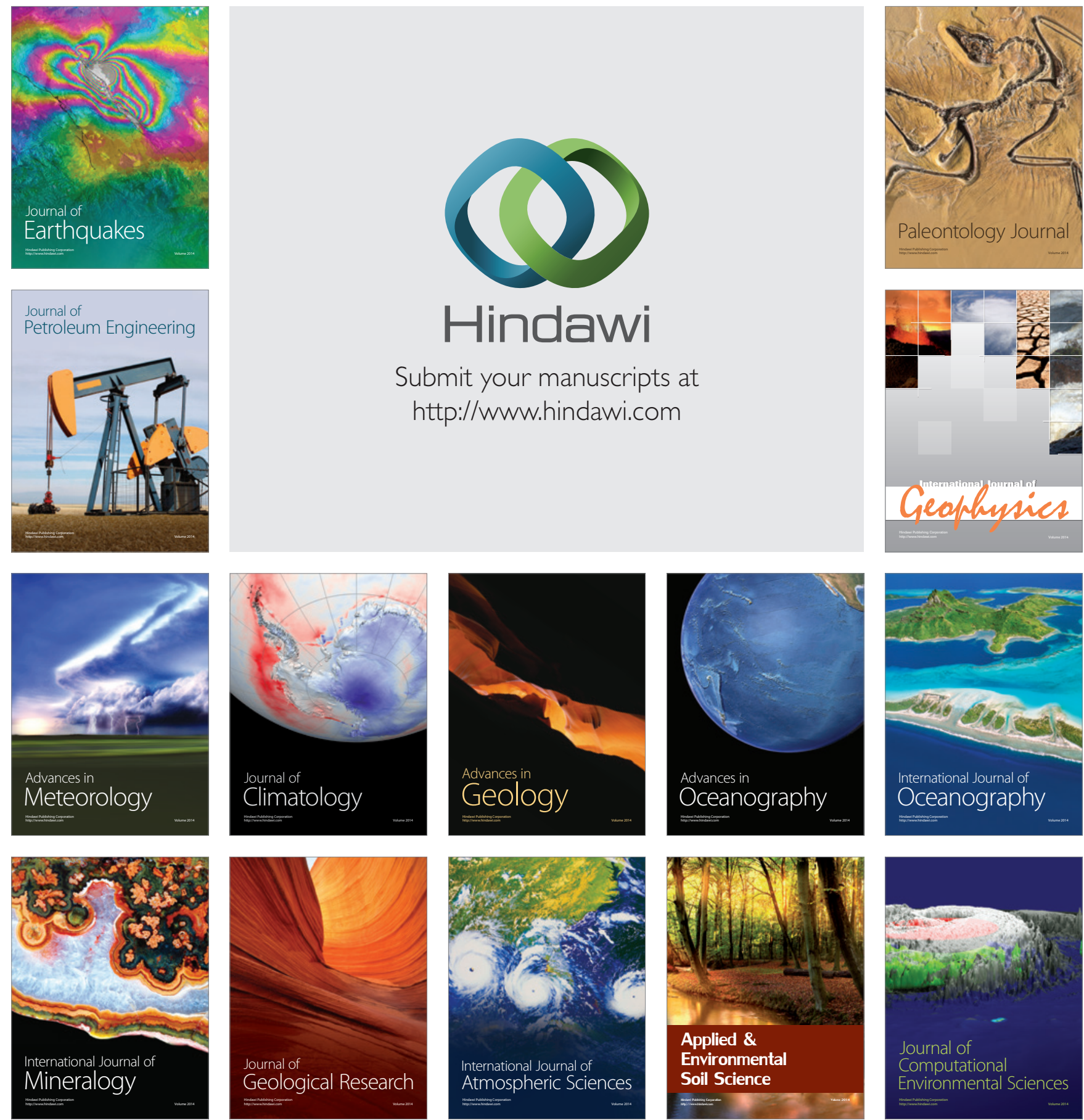